\title{
Epidemiology of hepatitis B virus in the cities of the northern region of Espírito Santo, Brazil
}

\author{
ANDRÉ M. FONTES ${ }^{1}$, JULIANA S. ARDISSON ${ }^{1}$, MARCO A.A. SOUZA ${ }^{3}$, \\ RODRIGO R. FREITAS ${ }^{2}$ and JOÃO A.T. PANCOTO ${ }^{1}$ \\ ${ }^{1}$ Universidade Federal do Espírito Santo, Departamento de Ciências Farmacêuticas, Avenida \\ Marechal Campos, 1468, Bairro Maruípe, 29043-900 Vitória, ES, Brasil \\ ${ }^{2}$ Universidade Federal do Espírito Santo, Departamento de Engenharia e Tecnologia, Rodovia \\ BR 101 Norte, Km 60, Bairro Litoranêo, 29932-540 São Mateus, ES, Brasil \\ ${ }^{3}$ Universidade Federal do Espírito Santo, Departamento de Ciências da Saúde, Rodovia BR \\ 101 Norte, Km 60, Bairro Litoranêo, 29932-540 São Mateus, ES, Brasil \\ Manuscript received on February 24, 2015; accepted for publication on March 11, 2016
}

\begin{abstract}
The World Health Organization (WHO) estimates that approximately 2 billion people worldwide have already had contact with hepatitis B virus (HBV) and 373 million have become chronic carriers. Hepatitis $\mathrm{B}$ is a major cause of chronic hepatitis, cirrhosis and hepatocellular carcinoma, leading to a large number of deaths annually. Both viral factors and the host immune response have been implicated in the pathogenesis and clinical result of HBV infection. Many Brazilian cities, including the cities of the northern region of the state of Espírito Santo are located in regions with little health infrastructure. Our study performed an epidemiological analysis of cases of Hepatitis B in São Mateus, using methodology of Geographic Information System (GIS), aiming to raise the number of disease cases, establishing preventive measures to control the disease, improving the quality of life of people affected by this pathology. The city of São Mateus had the largest number of reported cases of hepatitis B northern region of Espírito Santo. The age group with the highest number of hepatitis B notifications was 20-49 years, mostly females. The major forms of contact with HBV in these cities were dental treatment, use of injectable medications, surgical procedures and multiple sexual partners.
\end{abstract}

Key words: hepatitis B, epidemiology, geoprocessing, Espírito Santo.

\section{INTRODUCTION}

The hepatitis B virus (HBV) is considered a prototype member of the family Hepadnaviridae which is incorporated by DNA viruses with liver tropism (Marion 1988). HBV is a major cause of infection in humans and it can cause acute and chronic hepa-

Correspondence to: João Alexandre Trés Pancoto

E-mail: joao_pancoto@yahoo.com.br titis, cirrhosis, liver disease and hepatocellular carcinoma cell (Ganem and Prince 2004).

HBV transmission can occur through cuts (skin and mucosa), sexual contact, needles or other contaminated instruments, injecting drug use, blood transfusion, dental procedures or vertical transmission (through the placenta, at birth or during breastfeeding) (Ferreira and Silveira 2004). 
Currently, it is estimated that about 2 billion people have had contact with HBV, and of this number, approximately 373 million people have become chronic carriers of the disease (WHO 2014).

The prevalence of hepatitis $\mathrm{B}$ varies from region to region in the world and can be classified as areas of high prevalence $(>8 \%)$, intermediate $(2-8 \%)$ or low incidence $(<2 \%)$ (WHO 2014). In South America, for example, the prevalence varies between $2 \%$ and $8 \%$ (Fathimoghaddam et al. 2011).

In Brazil, at least $15 \%$ of the population has, at some point, had contact with HBV and about $1 \%$ has chronic hepatitis B (Ferreira and Silveira 2004). The highest prevalence of HBV in Brazil is in the Amazon River basin (Torres 1996), but other regions, such as part of Espírito Santo and the western cities of Paraná and Santa Catarina, also have a high prevalence (Souto 1999).

Geoprocessing, a set of tools used to manage spatial information, can be applied to further clarify some epidemiological issues of HBV infection, as full details of actions and their consequences to public health can be obtained (Barcellos et al. 2008).

In addition, data from the Notifiable Diseases Information System (SINAN) can be used to study georeferencing. For example, Skaba et al. (2004) reviewed the addresses stored in the system in order to offer viable alternatives to the Geographic Information System (GIS) and thus contribute to viability, in country, of spatial analysis in health micro-areas such as the northern region of the Espírito Santo.

The cities in the northern region of the Espírito Santo are located in regions with irregular distribution of health services. In particular, the city of São Mateus has only a small referral hospital to serve the city and other nearby towns.

This study aimed to clarify the latest information on hepatitis B using an epidemiological survey of confirmed cases of hepatitis B and georeferencing in the city of São Mateus and the cities that are part of the northern region of the Espírito Santo.

\section{MATERIALS AND METHODS}

This study was approved by the ethics committee of the Centro Universitário do Norte do Espírito Santo (CEUNES) at the Universidade Federal do Espírito Santo (UFES), protocol number 439272/2013. The study complies with all ethical standards for research.

The study used data from eleven cities in the northern part of the Espírito Santo: Boa Esperança (population 14239), Conceição da Barra (pop. 28599), Ecoporanga (pop. 23153), Jaguaré (pop. 2572), Montanha (pop. 17899), Mucurici (pop. 5636), Nova Venécia (pop. 46262), Pedro Canário (pop. 23935), Pinheiros (pop. 24093), Ponto Belo (pop. 7034) and São Mateus (pop. 110453).

Information on individuals diagnosed with hepatitis B and treated at the Testing and Counseling Center (CTA) of the São Mateus health department were obtained from the Regional Office of County Health which provided access to the SINAN database.

Data of the SINAN database were compiled in Microsoft Excel 2013 and converted to proportion of total population in each city. The compiled data were subjected to statistical analysis in the statistical software Primer and the results were grouped by similarity.

To identify clusters of HBV we used hierarchical clustering similarity (Cluster) using the BrayCurtis similarity index (Clarke and Warwick 1994) and non-metric multidimensional scaling (MDS). The hierarchical clustering linked the samples by their associations producing a dendrogram and a graph. The smaller the distance between the points, the greater the similarity between the samples (Moita Neto and Moita 1998). Another statistical test used was two-way ANOVA using Graphpad Prism software (version 1.5 CA, USA, 2000). To compare groups and other variables. These analyses were considered statistically different at $\mathrm{p}<0.05$. 


\section{RESULTS}

The cities of São Mateus, Pedro Canário and Jaguaré, had proportionally the largest numbers of reported cases of HBV infection in the period 2007 to 2013 (Figure 1).

Similarity analysis showed that in 2009 the number of cases was significantly different from other years. In 2009 there was a similarity of only $40 \%$ with the other cities (Figure 2a). In 2013, there was a marked reduction in the number of cases, as evidenced by similarity of only $60 \%$ with other years (Figure 2a). Similarity of $80 \%$ of cases of hepatitis B in all analyzed cities was observed in the years 2007, 2008, 2010, 2011 and 2012.

The cities of São Mateus, Pedro Canário and Jaguaré had the highest numbers of reported cases of hepatitis B during the study period. The city of
São Mateus showed only $20 \%$ similarity with the other cities, and Pedro Canário and Jaguaré showed $80 \%$ similarity (Figure $2 \mathrm{~b}$ ).

The city of São Mateus had significantly more notifications than Jaguaré and Pedro Canário $(\mathrm{p}<0.03)$ in the period 2009-2013. The cities of Jaguaré and Pedro Canário were also tested, however, statistically significant differences were found between the reports of numbers during the study period (Figure 3a).

When stratified by age, the 30-59 years age group were responsible for most hepatitis B notifications but there were no statistical differences between the cities of Jaguaré and Pedro Canário. However, in São Mateus there was a statistically significant difference compared with Jaguaré and Pedro Canário $(\mathrm{p}<0.0017)$ (Figure 3b).

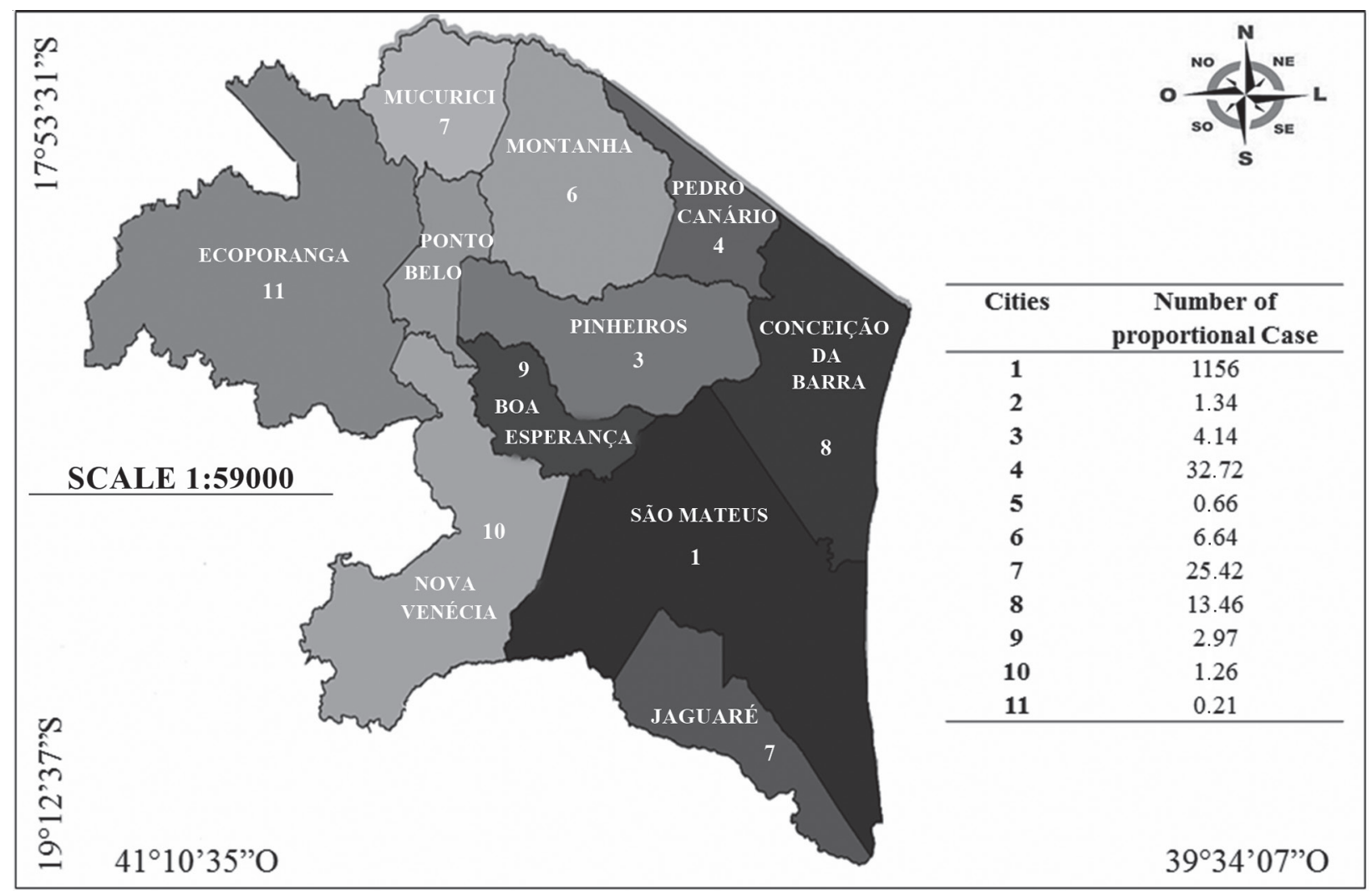

Figure 1 - Map of the northern region of the Espírito Santo. 


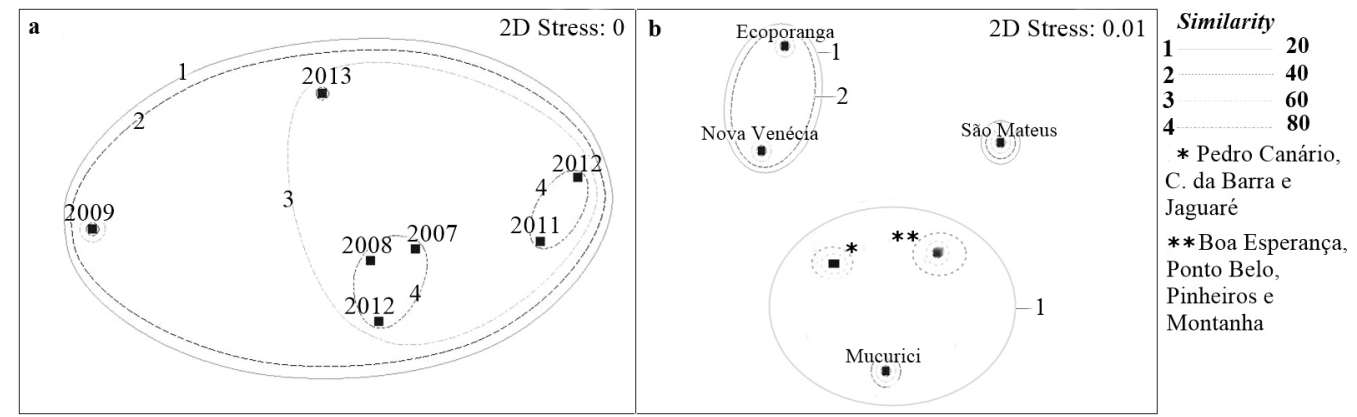

Figure 2 - Non Metric Multidimensional Scaling (MDS) - a) Similarity of the numbers of reported cases and cities in the Northern Region - ES as the profile of notifications in the years 2007 to 2013. b) Similarity of the cities in the Northern Region - ES as the profile of notifications in 2007 to 2013.

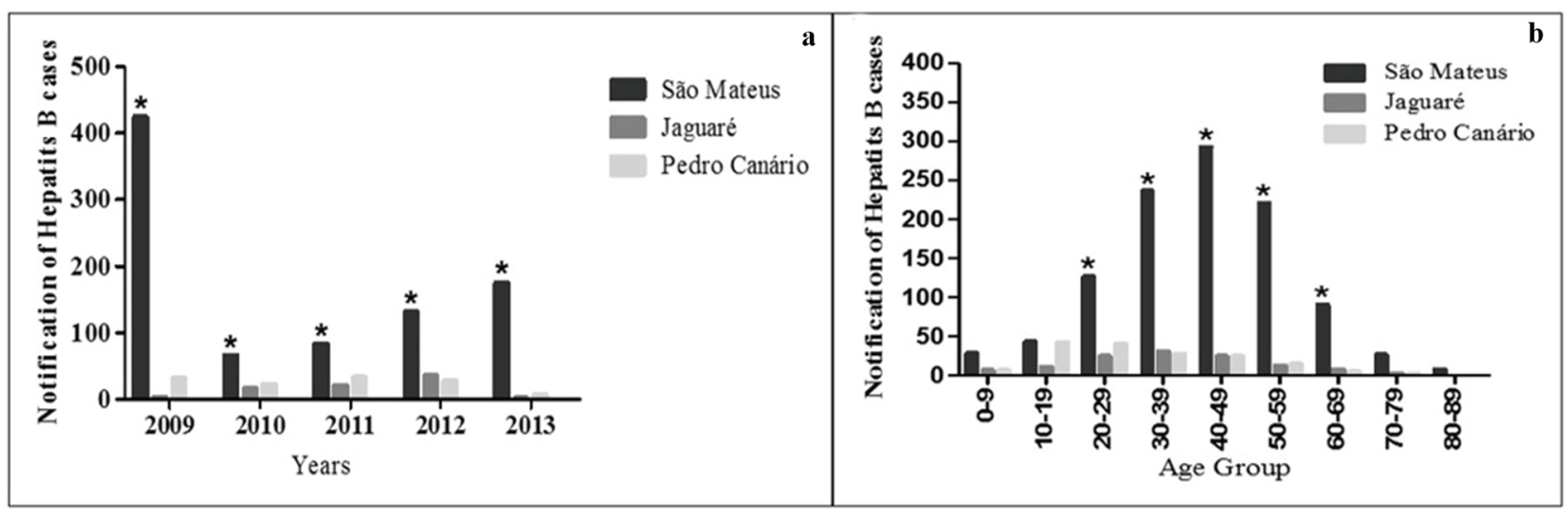

Figure 3 - Analysis between the notifications of Hepatitis B cases through the SINAN databases in the cities of the Northern Region of the Espírito Santo (São Mateus, Jaguaré and Pedro Canário). a) Number of reported cases from 2009 to $2013,{ }^{*}$ p $<0.0313$. b) Number of reported cases of hepatitis B from 2007 to 2013 stratified byage group, ${ }^{*} \mathrm{p}<0.0017$.

Considering the three cities that had the highest numbers of cases of hepatitis B and gender (male and female), there were no significant differences between the cities of Pedro Canário and Jaguaré, however, similar to the analysis by age group, we found a statistically significant difference by gender between São Mateus and the other cities tested, $\mathrm{p}<0.01$ (Figure 4).

Finally, as the route of contact of individuals with HBV, it was found that the city of São Mateus has no similarity between the other cities in the northern region and the possible ways of transmission of hepatitis B. As seen in Figure 5, the main forms of contact with HBV were through the use of injectable drugs and dental treatment, with approximately $95 \%$ similarity between them and through sexual and household contact with another carrier of HBV, with approximately $90 \%$ of similarity between them. Moreover, the form of contact with HBV in hemodialysis showed little similarity with other forms of contact, with only about $20 \%$.

\section{DISCUSSION}

There are few studies regarding hepatitis B in Brazil and those that do exist refer to specific groups rather than the population in general (Ferreira and Silveira 2004). Espírito Santo is no different, so we did an epidemiological study to remedy the deficiency in studies of the disease in the north of the state.

Of all cities in the northern region of the state, three cities São Mateus, Pedro Canário and Jaguaré 


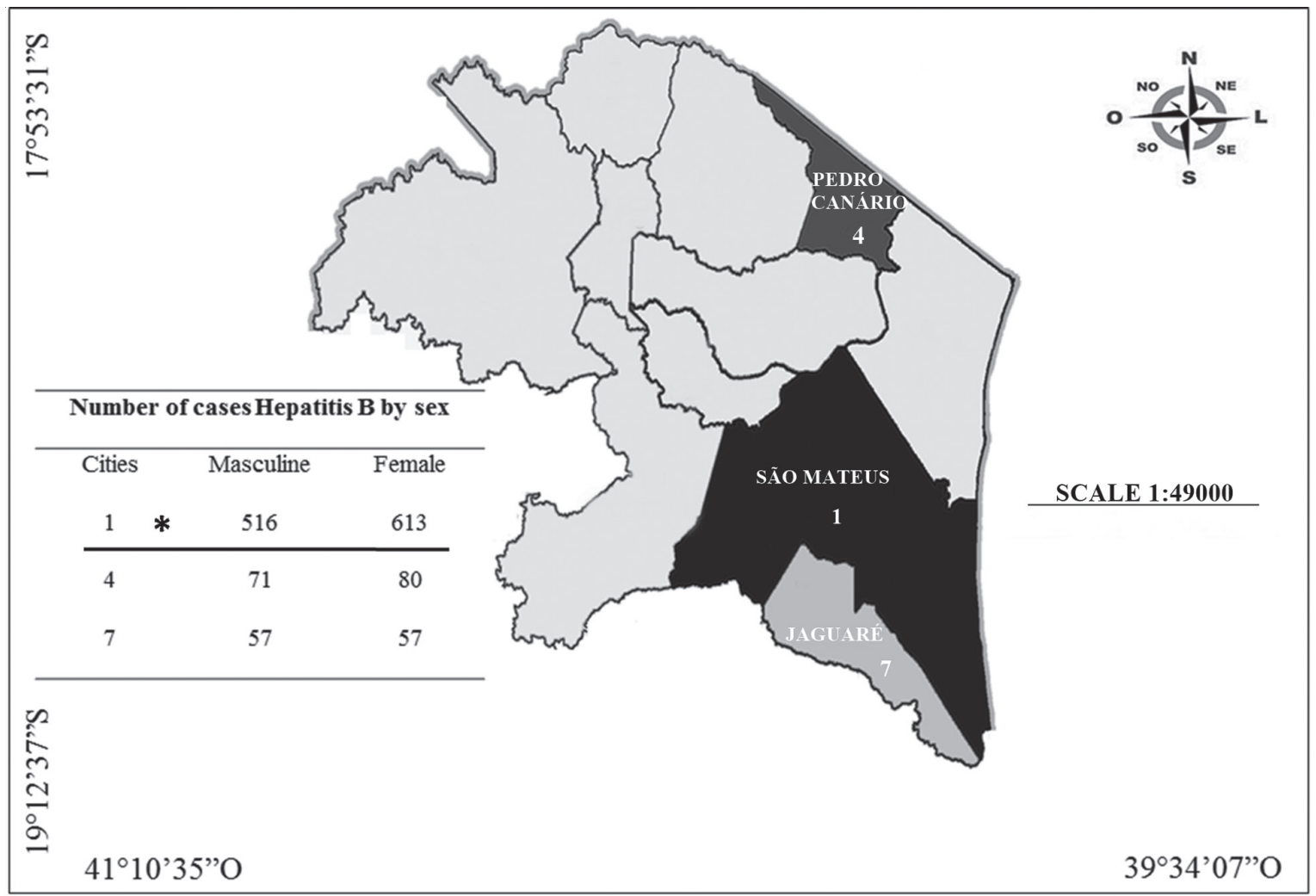

Figure 4 - Map of cities in the northern region had the highest number of notifications HBV stratified by gender.

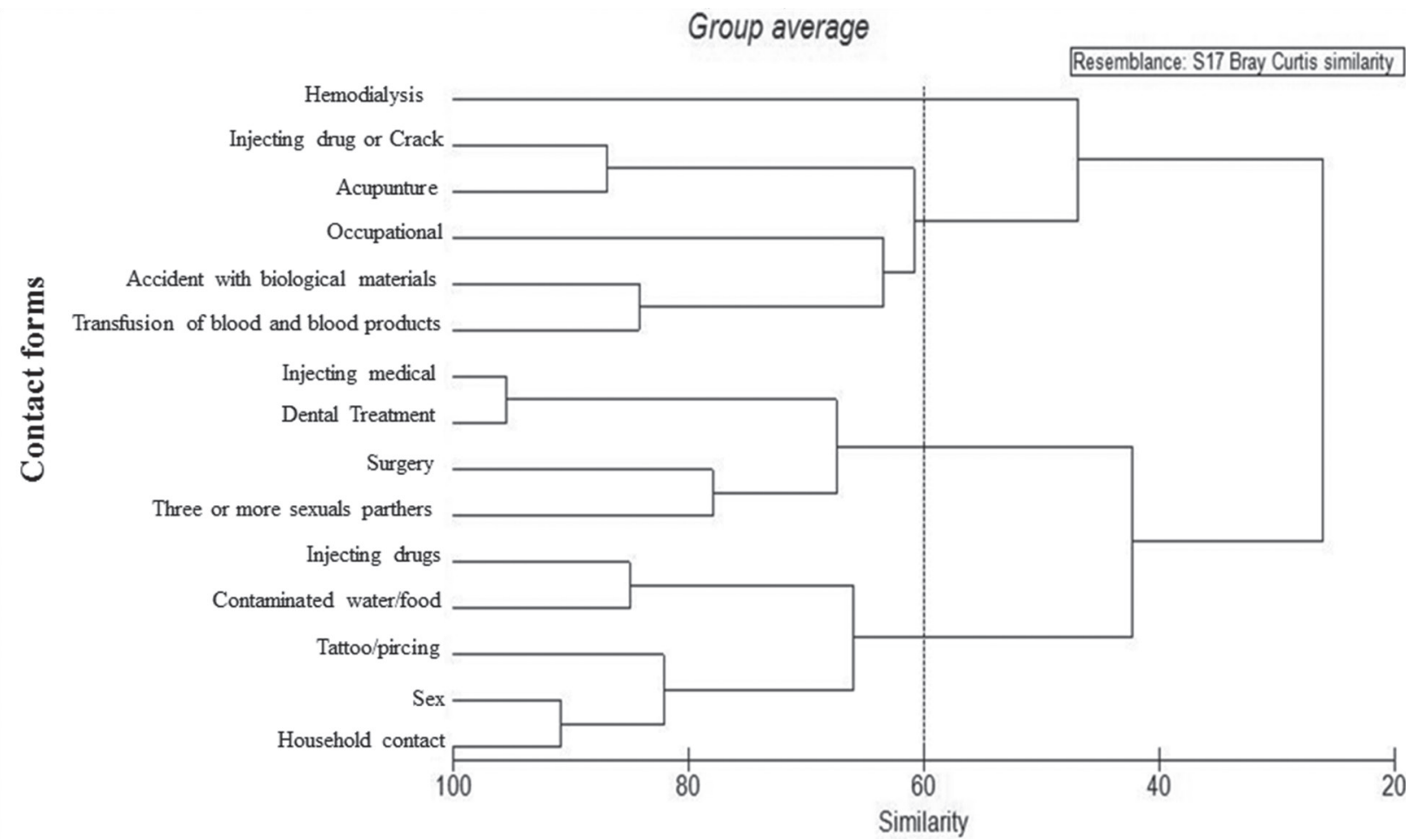

Figure 5 - Hierarchical Cluster Analysis - Dendrogram representing the contact forms of hepatitis in the cities of the Northern Region of the Espírito Santo and with timeline (2007-2013). 
had significantly higher numbers of notifications of hepatitis B. This may be linked to an inefficiency of the reporting systems of the other cities as reported in Epidemiological Bulletin of Viral Hepatitis Ministry of Health (Brasil 2012), or a genuinely lower incidence of hepatitis B.

Even after converting numbers to proportions, the city of São Mateus had much higher incidence of hepatitis B than other cities (20\% similarity). This may be because São Mateus hosts one of the headquarters of the Regional Health Superintendent of the State Health Secretariat of Espírito Santo and is considered a center of health administration in the north, as it performs all the dedicated care of the HBV cases from other cities.

The discrepancy between São Mateus and other cities may also be related to the fact the city has a blood bank. According to a study by Costa et al. (2012), all Brazilian regions with blood banks had a higher average rate of detection of hepatitis $\mathrm{B}$ than areas without this service because of greater access to laboratory diagnostics.

The greatest number of notifications was in the age group 30-59 years in the cities that had the highest number of cases, with $80 \%$ similarity between years. A study on the hepatitis B detection rate by age group and gender in Brazil and in the Southeast also found that the greatest number of cases occurred in the 30-59 year age group (Brasil 2012). Costa et al. (2012) observed that the age group most affected with hepatitis B varied by gender in Brazil, with greatest incidence in males aged 40-69 years and in women aged 15-39 years. These age groups are more likely to get hepatitis B because these age groups often have a lifestyle that has a high risk of transmission of HBV, particularly with respect to sexual activity and the number of partners (Chávez et al. 2003). Furthermore, the detection of hepatitis $B$ between the ages of 1 and 14 years in Brazil has decreased possibly due to the inclusion of the vaccine against HBV in the calendar of the National Immunization Program in 1997 (Brasil 2012).
Our study of the northern state of Espírito Santo also analyzed the number of notifications of hepatitis B stratified by gender in the three cities with the highest number of cases. In these cities females had higher rates of hepatitis B notification than males, which clashes with national data in which males were responsible for the largest incidence of the disease in Brazil (Brasil 2012). Previously, Clemens et al. (2000) found that the difference between the genders was not significant in Brazil and in the Southeast. However, in our study, a significant difference was found ( $p$ $<0.0106$ ) when comparing the city of São Mateus (highest number of notifications) with the cities of Pedro Canário and Jaguaré.

The main forms of contact with the virus in our study were through the use of injectable drugs and dental treatment, with approximately $95 \%$ similarity between them and the sexual way and the household contact with another with HBV, with approximately $90 \%$ of similarity between them. Moreover, the form of contact with HBV in hemodialysis showed little similarity with other forms of contact, with only about $20 \%$.

In contrast to our results, a study by Brasil et al. (2003) demonstrated that of the total population studied in the state of Amazônia, 24.6\% reported exposure to endemic area and $15.5 \%$ had percutaneous exposure before infection with HBV.

\section{CONCLUSIONS}

The city of São Mateus has the largest number of reported cases of hepatitis B in the northern region of Espírito Santo. The highest rates of notification of hepatitis B in the study area were in the age group 20-49 years, mostly females. The predominance of notifications in females is possibly because women tend to seek more health services, thus enabling diagnosis. The main forms of contact with HBV were dental treatment, use of injectable medications, surgical procedures and multiple sexual partners. Thus, we conclude 
that there is an impairment in quality of life of the population under study, exposing them to hepatitis $\mathrm{B}$ and other diseases.

\section{REFERENCES}

BARCELLOS C, RAMALHO W, GRACIE R, MAGALHÃES MAFM, FONTES MP AND SKABA D. 2008. Georreferenciamento de dados de saúde na escala submunicipal: algumas experiências no Brasil. Epidemiol Serv Saúde 17: 59-70.

BRASIL. 2012. Ministério da Saúde (MS). Boletim epidemiológico das hepatites viras. Brasília: MS.

BRASIL LM, FONSECA JCF, SOUZA RB, BRAGA WSM AND TOLEDO LM. 2003. Prevalência de marcadores para o vírus da hepatite B em contatos domiciliares no Estado do Amazonas. Rev Soc Bras Med Trop 26: 565-570.

CHÁVEZ JH, CAMPANA SG AND HAAS P. 2003. Panorama da Hepatite B no Brasil e no estado de Santa Catarina. Rev Panam Saúde Públ 14: 91-96.

CLARKE KR AND WARWICK RM. 2001. Change in Marine Communities, $2^{\text {nd }}$ ed., United Kingdom: Primer-E, Plymouth Marine Laboratory, chapter 5, p. 1-9.

CLEMENS SAC, FONSECA JCD, AZEVEDO T, CAVALCANTI A, SILVEIRA TR, CASTILHO MC AND CLEMENS R. 2000. Soroprevalência para hepatite A e B em quatro centros no Brasil. Rev Soc Bra Med Trop 33: $1-10$.

COSTA LG, PAULA RC AND IGNOTTI E. 2012. Detecção de infecção pelo vírus da hepatite $\mathrm{B}$ nos municípios brasileiros segundo cobertura dos serviços de hemoterapia, no período de 2001 a 2008. Epidemiol Serv Saúde 21: 617626.

FATHIMOGHADDAM F, HEDAYATI-MOGHADDAM MR, BIDKHORI HR, AHMADI S AND SIMA HR. 2011. The prevalence of hepatitis B antigen-positivity in the general population of Mashhad, Iran. Hepat Mon 11: 346-350.

FERREIRA CT AND SILVEIRA TR. 2004. Hepatites virais: aspectos da epidemiologia e da prevenção. Rev Bras Epidemiol 7: 483-487.

GANEM MD AND PRINCE AM. 2004. Hepatitis B Virus Infection - Natural History and Clinical Consequences. N Engl J Med 350: 1118-1129.

MARION PL. 1988. Use of animal models to study hepatitis B viruses. Prog Med Virol 35: 43-75.

MOITA NETO JM AND MOITA GC. 1998. Uma introdução à análise exploratória de dados multivariados. Quim Nova 21: 467-469.

SKABA DA, CARVALHO MS, BARCELLOS C, MARTINS PC AND TERRON SL. 2004. Geoprocessamento dos dados da saúde: o tratamento dos endereços. Cad Saúde Pública 20: 1753-1756.

SOUTO FJD. 1999. Distribuição da hepatite B no Brasil: atualização do mapa epidemiológico e proposições para seu controle. Gastro Endosc Dig 18:143-150.

TORRES JR. 1996. Hepatitis B and hepatitis delta virus infection in South America. Gut 38: 548-555.

WHO - WORD HEALTH ORGANIZATION. 2014. Hepatite B. [Internet]. [Acessado 2014 jun 26]. Available: http:// www.who.int/mediacentre/factsheets/fs204/en/. 